\title{
UPAYA MENINGKATKAN PRESTASI SISWA TERHADAP MATA PELAJARAN PEMBIBITAN TANAMAN DENGAN MATERI POKOK PEMBIAKAN TANAMAN SECARA VEGETATIF MELALUI PENERAPAN METODE PEMBELAJARAN BERBASIS INQUIRI
}

\author{
I. Ketut Sukarmen \\ SMK Negeri 2 Negara \\ e-mail: ketutsukaman@gmail.com
}

\begin{abstract}
Abstrak
Hasil pembelajaran mata pelajaran Pembibitan Tanaman dengan materi pokok Pembiakan Tanaman Secara vegetatif bagi siswa kelas $X$ semester Satu Program Keahlian Agribisnis Tanaman Pangan dan Holtikultura, SMK Negeri 2 Negara, untuk Tahun pelajaran 2015/2016, rendah yakni masih dibawah KKM dan kerjasama antar siswa, masih kurang, demikian juga interaksi dalam kelas belum optimal. Keadaan tersebut membuat pencapaian materi pembelajaran tentang Pembiakan Tanaman secara Vegetatif menjadi kurang efektif, siswa belum mencapai prestasi sesuai yang ditargetkan dalam tujuan pembelajaran. Untuk mengatasi permasalahan tersebut peneliti berupaya melakukan perbaikan - perbaikan melalui menerapkan pembelajaran dengan menggunakan metode pembelajaran berbasis inquiri pada mata pelajaran Pembibitan Tanaman dengan materi Pembiakan Tanaman Secara Pejetatif bagi siswa kelas X Semester I Program Keahlian Agribisnis Tanaman Pangan dan Holtikultura SMK Negeri 2 Negara. Tujuan penelitian ini adalah untuk mengetahui peningkatan pencapaian prestasi belajar mata pelajaran Pembibitan tanaman pada materi Pembibitan Tanaman secara vegetatif,bagi siswa kelas X Semester I Program Keahlian Agribisnis Tanaman pangan dan Holtikultura SMK Negeri 2 Negara, melalui penerapan metoda pembelajaran berbasis inquiri. Penelitian ini dilakukan dengan mengambil sampel sebanyak sebanyak 30 orang siswa.
\end{abstract}

Kata-kata kunci : Pembiakan Tanaman secara Vegetatif, Pembelajaran berbasis inquiri, Prestasi belajar mata pelajaran Pembibitan tanaman

\begin{abstract}
Learning outcomes of Plant Breeding subjects with Vegetative Plant Breeding subject for Tenth Grade students atthe first semester of the Food Crop and Horticulture Agribusiness Expertise Program, SMK Negeri 2 Negara, for the 2015/2016 academic year, which is still below the KKM and collaboration between students is still less, the interaction in the class is not optimal. This situation makes the achievement of learning material about Vegetative Plant Breeding to be less effective, students have not achieved the achievement as targeted in the learning objectives. To overcome these problems the researchers sought to make improvements through implementing learning using inquiry-based learning methods in the subject of Plant Breeding with the material of Plant Breeding in an Approximate manner for Tenth Grade students at the first Semester in the Agribusiness Expertise Program in Food Plants and Horticulture at SMK Negeri 2 Negara.. The purpose of this study was to determine the increasing learning achievement of plant nursery subjects in vegetative nursery material, for tenth grade students at the first Semester in the Food Crop Agribusiness and Horticultural Expertise Program at SMK Negeri 2 Negara, through the application of inquiry-based learning methods. This research was conducted by taking sample of 30 students.
\end{abstract}

Keywords: Vegetative Plant Breeding, Inquiry-based learning, Learning achievements in plant nursery subjects 


\section{Pendahuluan}

Prestasi belajar diartikan sebagai ukuran pengetahuan yang didapat dari pendidikan formal dan ditunjukkan melalui nilai tes (Lawrence \& Vimala, 2012). Selaras dengan pendapat tersebut, Goods dalam Annes (2013) mendefinisikan prestasi belajar sebagai pengetahuan yang dicapai maupun keterampilan yang dikembangkan pada berbagai mata pelajaran di sekolah yang biasanya ditentukan oleh nilai ujian maupun dengan nilai yang diberikan oleh guru, atau keduanya. Kpolovie, Joe, dan Okoto (2014) menambahkan bahwa prestasi belajar merupakan kemampuan siswa untuk belajar, yakni dengan mengingat fakta dan mengkomunikasikan pengetahuannya baik secara lisan maupun tertulis, bahkan dalam kondisi ujian. Jadi, pada intinya, prestasi belajar dapat dikatakan sebagai hasil yang diperoleh dari kegiatan pembelajaran di sekolah yang bersifat kognitif dan biasanya ditentukan melalui pengukuran dan penilaian (Izzaty, 2017).

Negara Pembelajaran tentang Pembibitan tanaman penting di berikan kepada siswa SMK Program Keahlian Agribisnis Tanaman Pangan dan Holtikultura, terutama untuk pemahaman tentang teknik Pembibitan tanaman. Siswa dapat menerapkan Teknik Pembibitan Tanaman dengan benar yang menyangkut :

1. Persyaratan pembibitan.

Dalam menerapkan persyaratan Pembibitan Tanbaman siswa dapat mengetahui tentang :

a. Lokasi : Lokasi yang ditentukan untuk pembibitan adalah lokasi yang dekat dengan sumber air atau kondisi perairannya bagus serta air tersedia pada lokasi yang telah ditentukan tersebut sepanjang tahun terutama untuk mengahadapi musim kemarau. Tersedianya jalan yang dapat dilalui oleh kendaraan roda dua dan roda empat untuk memudahkan sirkulasi pengangkutan kebutuhan pembibitan pada saat keluar dan masuk lokasi pembibitan tanaman atau kebun. Lokasi terpusat sehingga dapat memudahkan untuk melakukan pengawasan atau kontrol, serta luas lokasi disesuaikan dengan kebutuhan produksi bibit. Lahan pada lokasi pembibitan diupayakan datar dan drainase baik, sehingga program pembibitan tanaman dapat terlaksana dengan baik. Yang tidak kalah pentingnya adalah lokasi pembibitan tanaman terhindar dari gangguan ternak serta kondisi teduh menyejukkan.

b. Kesuburan Tanah : Kesuburan tanah pada lokasi tempat pembibitan tanaman memerlukan pengamatan siswa, bagaimana siswa dapat mengetahui kesuburan tanah yang akan dijadikan lokasi/ tempat pembibitan tanaman tersebut. Kesuburan tanah menjadi hal penting pula dalam mempersiapkan lokasi /tempat pembibitan Tanaman. Kesuburan tanah diperlukan untuk kebun koleksi pohon induk dan persemaian batang bawah, sehingga pertumbuhan dan produktivitas tanaman dapat optimal.Kesuburan tanah dapat menunjang kemudahan dalam memperoleh media semai dan media tanam dalam polybag.

c. Kondisi Iklim : daerah yang ideal untuk kondisi pembibitan tanaman adalah daerah yang bersuhu udara sejuk, kelembaban udara yang relatif tinggi, serta curah hujan yang cukup akan dapat menunjang pertumbuhan awal bibit tanaman.Namun untuk tanaman kebun produksi buah, justru sebaliknya di perlukan hari kering (kemarau), dan dalam perencanaan program pembibitan tanaman harus dibuat secara tegas yang terpisah dengan hari hujan karan hal ini dapat berpengaruh terhadap pembungaan dan cikal bakal pembuahan.

2. Pengolahan Pembibitan

a. Media Tumbuh dalam polybag : Syarat media yang tumbuh dengan baik adalah ringan, murah, mudah didapat, porus (gembur), subur ( kaya dengan unsur hara). Penggunaan media tumbuh yang tepat, akan menentukan pertumbuhan optimum bibit, yang ditangkar.

b. Komposisi media tanam untuk mengisi polybag, dapat digunakan campuran tanah, pupuk kandang dan sekam padi dengan perbandingan 1:1:1. Sumber: (Irham Zadani : dalam : http://www.scribd.com/TEKNIK-PEMBIBITAN-TANAMAN). 


\section{Cara Memilih Bibit Unggul Tanaman.}

Bibit tanaman yang baik dan berkualitas unggul merupakan faktor penunjang yang memiliki peran penting terhadap keberhasilan produksi agribisnis pertanian pada suksektor budidaya. Bibit tanaman yang berkualitas dengan mutu tinggi adalah bibit yang memenuhi syarat mutu genetik, mutu fisiologik (persentase tumbuh tinggi), dan mutu fisik. Tingginya permintaan konsumen terhadap produk-produk pertanian mengakibatkan kebutuhan sarana dan prasarana pertanian meningkat, termasuk dalam hal ini adalah permintaan akan bibit tanaman yang berkualitas unggul. Siswa yang sedang belajar tentang pertanian atau pembudidaya, baik yang mempelajari materi tentang melaksanakan proses budidaya dengan cara tradisional maupun materi tentang penerapan sistem budidaya pertanian secara intensif, pemahaman terhadap pemilihan bibit tanaman harus diajarkan secara konsisten agar dalam pelaksanaannya dapat dilakukan secara hati-hati serta dapat memilih bibit unggul yang sudah benar-benar teruji. Siswa memahami bagaimana caranya menghindari pemilihan bibit tanaman dengan keputusan yang sifatnya spekulatif. Dewasa ini seiring dengan perkembangan teknologi di sektor pertanian, pada saat yang sama juga diikuti dengan perkembangan organisme pengganggu tanaman yang semakin tidak terkendali. Mengandalkan kemampuan dan daya bunuh pestisida untuk mengendalikan tingkat serangan organisme pengganggu tanaman (OPT) bukanlah hal yang bijak, mengingat kondisi lahan pertanian yang semakin hari semakin kritis serta komitmen untuk tetap menjaga lingkungan agar tetap sehat dan mengurangi tingkat paparan pestisida pada manusia. Disamping itu, tingkat kekebalan organisme pengganggu tanaman atau dalam dunia pertanian dikenal dengan istilah resistensi terhadap bahan aktif pestisida tertentu yang beredar di pasaran, tentu saja akan membuat biaya produksi membengkak, baik dengan meningkatkan dosis pestisida yang digunakan maupun memperpendek intervalaplikasi pestisida. Pengetahuan ini diberikan kepada siswa dalam pembelajaran pembibitan tanaman. Bagaimana caranya memilih bibit yang berasal dari tanaman induk berkualitas. Sebelum membuat bibit (Contoh bibit cabai), sebaiknya menentukan tanaman yang akan dijadikan sebagai induk. Tanaman induk harus memiliki kriteria sebagai tanaman unggul, seperti pertumbuhan cepat, vigor, mampu beradaptasi di berbagai lingkungan, memiliki daya tahan yang baik terhadap serangan hama penyakit, responsif terhadap pemupukan, mampu berproduksi tinggi, serta menghasilkan buah dengan kriteria yang dikehendaki. Bibit harus dihasilkan dari buah yang benar-benar sudah tua, sehingga akan diperoleh biji yang benar-benar bernas. Memiliki daya kecambah yang bagus, bibit harus memiliki pertumbuhan yang bagus selama dalam persemaian. Bibit dengan pertumbuhan bagus akan menghasilkan tanaman yang subur, sedangkan bibit yang mengalami keterlambatan pertumbuhan selama dalam persemaian, maka laju pertumbuhan setelah penanaman di lahan akan mengalami keterlambatan.Pilih bibit yang sehat, tidak terserang hama penyakit.

Dengan menerapkan cara tersebut di atas,siswa akan dapat memahaminya bagaimana caranya untuk mendapatkan bibit yang mampu mendukung keberhasilan usaha budidaya tanaman ya

A. Ruang lingkup Materi Mata Pelajaran Pembibitan Tanaman

1. Teknik perbanyakan tanaman dengan menggunakan bagian-bagian vegetatif tanaman seperti tunas, batang, akar.

2. Kualitas genetik yang unggul,

3. Pengaruh terhadap metoda stek nuntuk pembenihan.

4. Langkah-langkah Pembiakan Tanaman Secara Pejetatif,

5. Prinsip dasar Pembiakan tanaman Secara Pejetatif

6. Kultur jaringan

7. aspek lingkungan yang mempengaruhi lajunya pertumbuhan benih tanaman.

8. Kendala - kendala dalam pembiakan tanaman Secara Pejetatif,

9. Cara Penanggulangannya. 


\section{B. Pentingnya Pembelajaran Pembibitan Tanaman Bagi Siswa Smk Program Keahlian Agribisnis Tanaman Pangan Dan Holtikultura.}

Dari hasil belajar menyiapkan bibit terkait penyiapan media pembibitan, penyapihan bibit, pemeliharaan bibit dan pemindahan bibit (transplanting) sebagai kesiapan menjadi untuk terjun dalam bidang pertanian dan petani bibit tanaman hortikultura, maka pembelajaran pembibitan tanaman sangatlah penting untuk dipelajari oleh siswa SMK Program Keahlian Agribisnis Tanaman Pangan dan Holtikultura. Pembelajaran yang diterapkan menggunakan pembelajaran dengan pendekan inquiry, dapat membantu siswa dalam menemukan, mencari solusi terhadap materi yang ditugaskan dan terkait dengan pembibitan tanaman. Sebagaiman yang telah diungkapkan pada bagian terdepan bahwa teknik pembibitan tanaman dapat diajarkan pada siswa sesuai dengan proses pembelajaran pembibitan tanaman. Manfaat hasil belajar menyiapkan bibit sebagai kesiapan siswa menjadi petani bibit tanaman hortikultura adalah tuajuan yang akan dicapai pada akhir pembelajaran. Dalam pembelajaran Pembibitan Tanaman siswa perlu tahu bagaiman peranan lingkungan dalam aspek kehidupan bibi tanaman dan orgnisme lain yang berpengaruh. Oleh sebab itu pengetahuan tentang pembibitan tanaman dan aspek lingkungan tumbuhnya tanaman sangat dibutuhkan agar kegiatan pembenihan tanaman dan budidaya tanaman yang dilakukan dapat menghasilkan produksi yang optimum.

C. Faktor-Faktor Penyebab Rendahnya Hasil Pembelajaran Siswa Smk Negeri 2 Negara

Prestasi belajar mata pelajaran pembibitan tanaman yang diperoleh siswa kelas $X$ Semester Satu Program keahlian Agribisnis Tanaman dan Holtokultura rendah dan partisipasi siswa dalam pembelajaran pun juga rendah. Ada beberapa hal yang menjadi penyebab rendahnya prestasi siswa berdasarkan pengamatan awal adalah :

1. Faktor Minat Belajar Siswa

Minat belajar siswa terhadap mata pelajaran Pembibitan Tanaman masih rendah, dan siswa cenderung mengalami kesulitan untuk memahami konsep-konsep Pembibitan Tanaman secara utuh. Hal ini menjadi perhatian utama dalam Penelitian Tindakan kelas ini.

2. Faktor Perhatian Siswa.

Perhatian siswa sering terganggu oleh pikiran mereka yang kurang fokus dalam mengikuti penjelasan konsep Pembibitan Tanaman, sehingga pemahamannya menjadi rendah.

3. Metoda mengajar

Dalam memberikan pembelajaran yang bersifat akademik guru menjelaskan tentang konsep pembenihan Tanaman lebih banyak menggunakan metoda ceramah, sehingga siswa cenderung bosan dan mengantuk, sehingga daya serap siswa terhadap mata pelajaran dalam pembelajaran di kelas menjadi rendah dan hal ini berdampak terhadap rendahnya prestasi belajar siswa.Jika metoda pembelajaran mata pelajaran yang dilaksanakan dalam pembelajaran bagi siswa kurang tepat maka prestasi hasil pembelajaran yang diperoleh siswa selalu rendah. Demikianlah yang dialami oleh siswa kelas X semester Satu Program keahlian Agribisnis Tanaman pangan da Hortikultura SMK Negeri 2 Negara

\section{Pembiakan Tanaman Secara Vegetatif}

Dengan pembiakan tanaman melalui teknik vegetatif atau cara reproduksi tanaman aseksual ( tanpa adanya peleburan sel kelamin jantan dan betina. Tanaman termasuk salah satu makhluk hidup dalam mempertahankan eksistensinya memerlukan pemikiran secara ilmiah dari para pakar atau ilmuwannya. Reproduksi secara vegetatif bisa terjadi secara alami maupun buatan. Misalkan pada hewan secara alami melakukan perkembangbiakan dengan membelah diri. Sedangkan pada hewan perkembangan dengan membelah diri biasanya terjadi pada kelompok hewan tingkat rendah, yang mempunyai sel satu/protoza, seperti : amoeba dan paramaecium. Pembelahan diri biner jika terjadi pembelahan individu menjadi 2 individu baru, dan disebut pembelahan diri multipel (perkembangbiakan dengan spora) jika pembelahan 
individu menjadi banyak individu, misalnya: plasmanium Partenogenesis : suatu kempuan pada komodo untuk dapat melahirkan tanpa sel sperma. Sedangkan Fragmentasi : Pada hydra, bintang laut, pada hewan dan binatang laut lainnya seperti ubur-ubur, porifera, serangga, lebah, kutu. Sedangkan pembviakan atau reproduksi vegetatif alami adalah reproduksi aseksual yang terjadi tanpa campur tangan pihak lain seperti manusia, tanaman membelah sendiri dan kejadian ini terjadi secara alami jika tanaman tersebut telah mencapai batas waktu tertentu untuk melakukan pembelahan secara sendiri.

Suatu pembelahan diri terjadi pada tumbuhan secara alami, yang terdapat pada tunas daun. Adapun jenis tanaman lainnya yang dapat melakukan reproduksi secara alami adalah :

a. Umbi batang. Contoh: bangkuang, kentang

b. Umbi lapis. Contoh: bawang merah, bawang putih, bawang bombay, tulip, bunga bakung

c. Umbi akar. Contoh: wortel, singkong, lobak

d. Geragih atau stolon. Contoh: rumput teki, stroberi, arbei.

e. Rizoma atau akar tinggal. Contoh: lengkuas, jahe, kunyit

f. Tunas. Contoh: pisang, bambu, tebu, nanas.

g. Tunas adventif. Contoh: cocor bebek

h. Membelah diri. Contoh : Ganggang Hijau

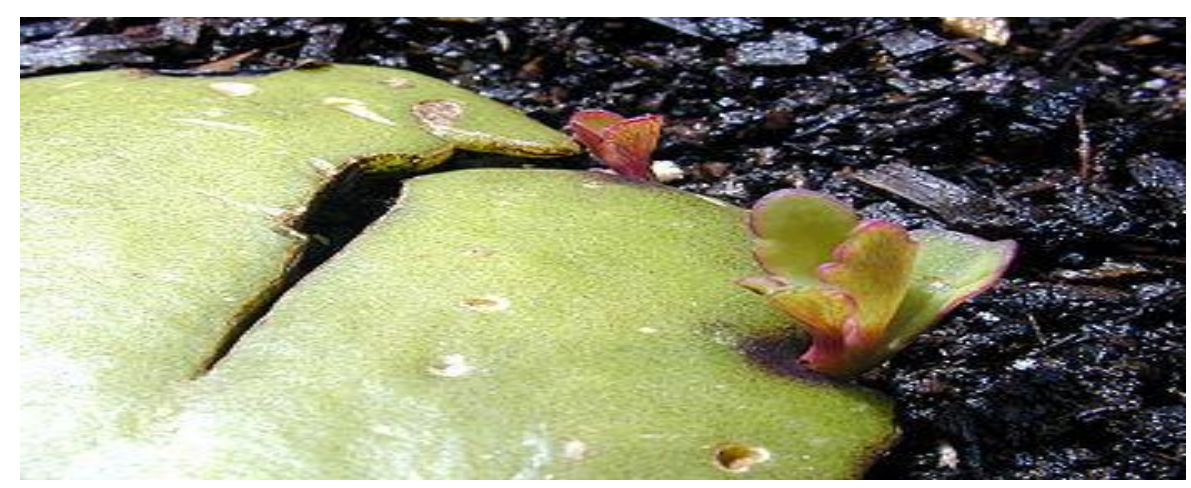

Gambar 1. Vegetatif alami secara tunas adventif/ tunas daun

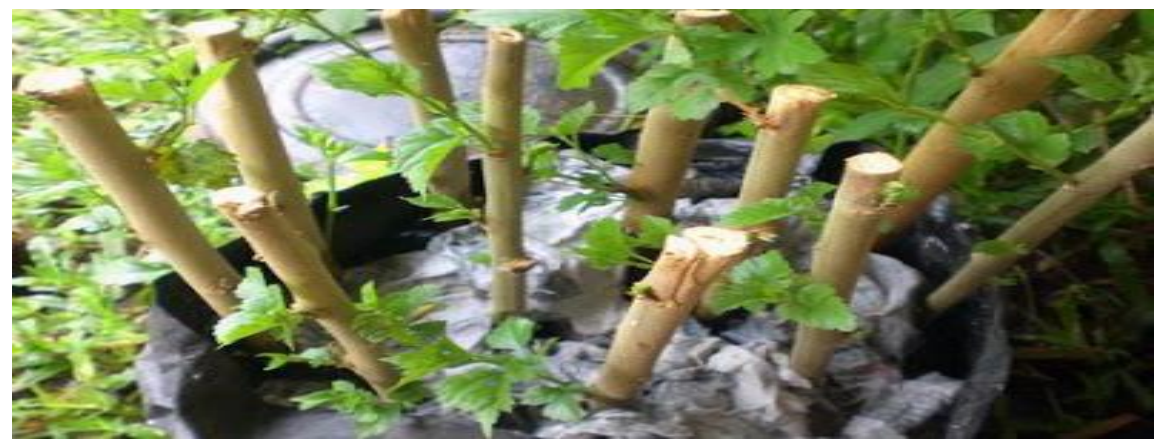

Gambar 2. Pembiakan Vegetatif Dengan Menggunakan Stek

Pembiakan Vegetatif Dengan Menggunakan Stek, suatu perlakuan pemisahan, pemotongan beberapa bagian tanaman (akar, batang, daun dan tunas) dengan tujuan agar bagian - bagian itu membentuk akar. 
E. Tujuan Penelitian adalah untuk :

Tujuan yang ingin dicapai dalam penelitian ini sesuai dengan rumusan masalah diatas adalah sebagai berikut :

1. Untuk meningkatkan prestasi belajar siswa dengan menggunakan metode pembelajaran berbasis Inquiri pada mata pelajaran mata pelajaran Pembibitan tanaman pokok Pembiakan Tanaman Secara Vegetatif bagi siswa kelas X Semester I Program Keahlian agribisnis tanaman Holtikultura SMK Negeri 2 Negara

2. Untuk meningkatkan prestasi belajar siswamelalui penerapan metoda pembelajaran berbasis Inquiri mata pelajaran Pembibitan tanaman pokok Pembiakan Tanaman Secara Vegetatif bagi siswa kelas $X$ Semester I Program Keahlian agribisnis tanaman Holtikultura SMK Negeri 2 Negara.

3. Untuk mengetahui ketepatan penerapan metode pembelajaran berbasis Inquiri dalam pembelajaran mata pelajaran Pembibitan tanaman pokok Pembiakan Tanaman Secara Vegetatif bagi siswa kelas $X$ Semester I Program Keahlian agribisnis tanaman Holtikultura SMK Negeri 2 Negara.

4. Untuk mengoptimalkan pemahaman siswa kelas X Semester I Program Keahlian agribisnis tanaman Holtikultura SMK Negeri 2 Negara terhadap materi pelajaran Pembibitan tanaman pokok Pembiakan Tanaman Secara Vegetatif.

Untuk memperoleh gambaran tentang peningkatan prestasi belajar siswa pada mata pelajaran Pembibitan tanaman dengan materi pokok Pembiakan Tanaman Secara Vegetatif bagi siswa kelas X Semester I Program Keahlian agribisnis tanaman Holtikultura SMK Negeri 2 Negara

\section{Metode}

Tempat Penelitian ini adalah Penelitian Tindakan kelas sehingga metoda yang digunakan adalah metoda deskriptif analitis melalui PTK, yaitu studi yang digunakan untuk mengumpulkan data, mendeskripsikan, mengolah, menganalisa, menafsirkan dan menyimpulkan data sehingga diperoleh gambaran yang sistematis. Penelitian ini dilakukan di Kelas X Semester satu SMK negeri 2 Negara.

Subjek penelitian sebanyak 30 orang siswa. Kelas itu dijadikan sebagai subjek penelitian karena rata-rata hasil tes awal (pra siklus) hanya mencapai $60 \%$ siswa yang mencapai nialai diatas KKM sedangkan sebanyak $40 \%$ siswa yang memperoleh nilai dibawah KKM, sehingga perlu segera ditangani.

Teknik Pengumpulan Data dilakukan dengan menggunakan istrumen yang tertdiri dari : a) Tes Uji Kompetensi, b) Angket siswa, c) Lembar observasi, d) Wawancara, dan e) Refleksi

1. Prosodur penelitian dilaksanakan melalui tahapan-tahapan sebagai berikut :
a. Menyusun RPP
b. Memilih masalah
c. Studi pendahuluan
d. Merumuskan permasalahan
e. Memilih Pendekatan
f. Menentukan variabel
g. Menentukan sumber data
h. Mempersiapkan alat dan bahan
i. Menyusun instrument tes uji komptensi dan lembar observasi

2. Pelaksanaan Tindakan (Acting) Kegiatan yang dilaksanakan pada tahap ini adalah melaksanakan pembelajaran sebagaimana scenario pembelajaran yang telah ditetapkan pada RPP Melakukan perbaikan-perbaikan pada persiapan serta mekanisme pembelajarannya.

3. Pengamatan (observasi) Pada tahap ini dilakukan proses observasi terhadap pelaksanaan tindakan menggunakan lembar observasi yang telah dibuat.Observasi dilaksanakan dengan berkolaborasi dengan guru mata pelajaran lainnya di SMK Negeri 2 Negara sebagai kolaborator. 
4. Refleksi (Refleting) Setiap siklus saling berkaitan dan berhubungan, karena hasil refleksi akan digunakan sebagai acuan untuk perbaikan pada siklus berikutnya. Diharapkan setiap siklus ada peningkatan yang signifikan mengenai peningkatan pembelajaran Pembibitan Tanaman, sehingga hasil akhir akan maksimal. Peneliti mengadakan perubahan dan peningkatan dalam pelaksanaan pembelajaran di setiap siklus. Pada tahap refleksi atau tindakan dilakukan perbaikan atau penyempurnaan bagi siswa yang belum mencapai nilai sesuai dengan yang telah di persyaratkan.

\section{Hasil dan Pembahasan}

\section{Pembahasan Siklus I}

Hasil prestasi belajar siswa pada siklus telah terjadi peningkatan dari pra siklus dan jumlah rata - rata telah mencapai diatas KKM. Hal ini menunjukkan proses pembelajaran yang telah mulai efektif dan materi yang disampaikan oleh guru tentang Pembiakan tanaman secara vegetatif melalui penerapan metoda pembelajaran berbasis inquiri secara bertahap dapat meningkatkan prestasi belajar siswa. Hal ini dibuktikan bahwa hanya $65 \%$ siswa (19 orang) yang memperoleh nilai diatas KKM, sedangkan, $35 \%$ Siswa (11 orang) yang mendapat nilai dibawah KKM. Artinya sebanyak $35 \%$ siswa dari 30 orang harus diperbaiki nilainya. Adapun nilai rata-rata kelas memperoleh angka 73,36, untuk ulangan harian pada siklus I, hal ini perlu dilakukan tindakan /refleksi pada siklus berikutnya.

\section{Pada siklus ke II,}

Penerapan metode pembelajaran berbasis inquiri, lebih diefektifkan pada siklus II ini, sehingga mampu meningkatkan prestasi belajar siswa dan gairah belajar serta membantu guru dalam melaksanakan pembelajaran Pembibitan Tanaman secara lebih baik. Hasil prestasi belajar memperoleh nilai yang lebih baik serta adanya peningkatan perestasi siswa. Hal ini dapat dibuktikan dari hasil nilai yang diperoleh siswa pada siklus II ini adalah sebanyak 27 ( $85 \%$ ) orang siswa yang memperoleh nilai diatas KKM , sebanyak 3 (15\%) orang siswa yang mendapat nilai dibawah KKM. Adapun jumlah nilai rata-rata pada siklus II ini adalah 78,1. Dengan dilakukan refleksi secara maksimal maka pada siklus III ternyata adanya peningkatan hasil yang dicapai oleh siswa .

\section{Pada siklus III,}

Dengan diterapkannya metode pembelajaran berbasis inquiri secara konsisten dan Peneliti lebih memfokuskan diri dalam pelaksanaan tindakan pada siklus III ini, sehingga mampu meningkatkan prestasi hasil belajar siswa dan gairah belajar serta membantu guru dalam melaksanakan pembelajaran Pemkbibitan Tanaman secara lebih baik. Peningkatan prestasi belajar siswa memperoleh nilai yang lebih baik. Hal ini dapat dibuktikan dari hasil nilai yang diperoleh siswa pada siklus III ini adalah sebanyak 30 orang siswa (100\%) orang siswa yang telah memperoleh nilai diatas KKM , sebanyak 30 orang siswa $(100 \%)$ siswa yang telah meningkat prestasi belajarnya pada siklus III ini Adapun jumlah nilai rata-rata pada siklus III ini adalah 82,4.

Dengan dilakukan refleksi secara maksimal maka pada siklus III telah terjadi peningkatan hasil belajar Pembibitan Tanaman bagi siswa kelas X Semester Satu Program Keahlian Agribisnis Tanaman pangan dan Holtikultura SMK Negeri 2 Negara.

\section{Simpulan dan Saran}

Berdasarkan Penelitian Tindakan Kelas (PTK), yang dilaksanakan di kelas X Semester Satu Pada Program Keahlian Agribisnis Tanaman Pangan dan Holtikultura, telah menghasilkan suatu kesimpulan. Berdasarkan hasil tindakan / refleksi dari siklus I, Siklus II, Siklus III dapat disajikan kesimpulan bahwa :

1. Metoda pembelajaran berbasis inquiri yang diterapkan dalam pembelajaran mata pelajaran Pembibitan Tanaman dapat meningkatkan prestasi belajar siswa kelas $X$ semester satu 
Program Keahlian Agribisnis Tanaman pangan dan Holtikultura SMK Negeri 2 Negara pada mata pelajaran Pembibitan Tanaman. hal ini tergambar dari nilai rata-rata prestasi yang dicapai siswa pada siklus I mencapai 73,36, dan ada peningkatan sebesar 6,2 dari prasiklus.

2. Setelah dilakukan penyempurnaan terhadap RPP dengan memfokuskan pada penemuan jawaban atas pertanyaan oleh siswa maka pada siklus II prestasi belajar siswa kelas $\mathrm{X}$ semester satu Program Keahlian Agribisnis Tanaman pangan dan Holtikultura SMK Negeri 2 Negara setelah dilakukan tindakan/refleksi pada siklus II terjadi peningkatan dari siklus I dengan jumlah rata-rata nilai mencapai 78,1 dan terjadi peningkatan sebanyak 4,74 dari siklus I. Meskipun telah terjadi peningkatan jumlah rata-rata pada siklus II, namun masih ada sebanyak 3 orang ( $5 \%$ ) siswa yang memperoleh nilai di bawah KKM.

3. Dari hasil tindakan/refleksi yang dilakukan pada siklus III, maka peningkatan prestasi belajar mata pealajaran Pembibitan tanaman dengan materi Pembibitan Tanaman secara Vegetatif bagi siswa kelas $\mathrm{X}$ semester satu Program Keahlian Agribisnis Tanaman pangan dan Holtikultura SMK Negeri 2 Negara, dapat dicapai. Hal ini tergambar dari rata-rata nilai pada siklus III mencapai 82,4 dan meningkat sebesar 4,3 dari siklus II.

Dengan demikian penerapan metode pembelajaran berbasis inquiri dalam pelajaran Pembibitan tanaman dengan materi Pembiakan Tanaman secara Vegetatif, ternyata tepat dan prestasi belajar siswa dapat meningkat.Peningkatan prestasi belajar siswa dapat dicapai dari siklus I, siklus II serta siklus III mencapai 73,36 (pada siklus I),78,1 ( Pada siklus II ) da 82,4 ( Pada siklus III).

Setelah melaksanakan penelitian dan melihat hasil yang dicapai, maka peneliti menyarankan sebagai berikut :

1. Untuk mencapai dan meningkatkan mutu pembelajaran di SMK Negeri 2 Negara pada Program Keahlian Agribisnis Tanaman pangan dan Holtikultura, guru dapat melakukan Penelitian Tindakan Kelas dan menerapkan metode yang tepat dalam mengajarkan materi sesuai mata pelajaran yang diajarkan. Karena melalui Penelitian Tindakan Kelas ini dapat dilakukan perbaikan-perbaikan serta tindakan dalam bentuk refleksi bagi siswa yang belum mencapai hasil sesuai yang di standartkan.

2. Untuk melaksanakan pembelajaran melalui penerapan metode berbasis inquiri pada mata pelajaran Pembibitan Tanaman dengan materi Pembiakan Tanaman secara Vegetatif bagi siswa kelas X semester satu Program Keahlian Agribisnis Tanaman pangan dan Holtikultura SMK Negeri 2 Negara, guru memerlukan persiapan yang baik, sehingga guru harus mampu menentukan pembelajaran secara tepat.

3. Jika persiapan telah dilakukan secara matang hasil yang diperoleh akan jauh lebih baik dibandingkan dengan persiapan yang kurang baik. Dengan kosentrasi serta fokus pada refleksi terhadap kelemahan-kelemahan siswa maka peningkatan prestasi hasil pembelajaran siswa dapat dicapai.

4. Kepada para guru diharapkan dapat memberikan latihan-latihan yang cukup dan persiapan yang baik terhadap pendukung pembelajaran mata pelajaran yang diajarkan sesuai metoda pembelajaran yang diterapkan untuk mempersiapkan mereka dalam mengatasi masalah yang dihapinya.

\section{Daftar Pustaka}

Ariknto, Suhardjono, Supardi. 2006. Penelitian Tindakan Kelas. Jakarta: Bumi Aksara.

Depdiknas. 2001. Buku 1 Manajemen Peningkatan Mutu Pendidikan Berbasis Sekolah. Jakarta: Depdiknas.

Depdikna.2002. Petunjuk Pelaksanaan Penilaian Kelas di SD, SDLB, SLB Tingkat Dasar, dan MI. Jakarta: Depdiknas. 
Fenica, I., Muderawan, I. W., \& Widiartini, P. (2017). Implementasi Model Pembelajaran Inkuiri Untuk Meningkatkan Aktivitas Belajar Siswa Pada Mata Pelajaran Kimia. Jurnal Pendidikan Kimia Indonesia, 1(1), 1-6.

Hamalik. 1994. Media Pendidikan. Bandung : Citra Aditya Bakti

Indra Jati Sidi. 2004. Pelayanan Profesional, Kegiatan Belajar-Mengajar yang Efektif. Jakarta: Puskur Balitbang Depdiknas.

Izzaty, Rita Eka. 2017. Prediktor Prestasi Belajar Siswa Kelas 1 Sekolah Dasar. Jurnal Psikologi Volume 44, Nomor 2, 2017

Nasution. 1996. Metode Research. Jakarta: Bumi Aksar

Nasution. 2000. Didaktik Asas-asas Mengajar. Jakarta: Bumi Aksara

Nasution .2005. Berbagai Pendekatan Dalam Proses Belajar Mengajar.Jakarta: Bumi Aksara

Nana Sudjana. 2002. Penilaian Hasil Proses Belajar Mengajar. Bandung: Remaja Rosdakarya.

Puskur Balitbang Depdiknas. 2003. Model-model Pembelajaran Efektif. (www.puskur_balitbang_depdiknas.com).upadate 28 Agustus 2007.

Rohani, Ahmad. 1997. Media Instruktsional Edukatif. Jakarta: Rineka Cipta

Rahadi, Ansto. 2003. Media Pembelajaran Jakarta : Dikjen Dikti Depdikbud

Sudjana. 2001. Media Pengajaran. Jakarta : Sinar Baru Algensindo

Tim Penyusun, 2003, Belajar Sejarah dan Budaya, Jakarta: Elex Media Komputindo 